\title{
Studies on Zinc Retention in Sheep
}

\author{
T.R.M. Abov-Hussein, E.A. Grhad and \\ SABBAH M. ALLAM
}

Animal Production Department, Facully of Agricullure, Cairo University, A.R.E.

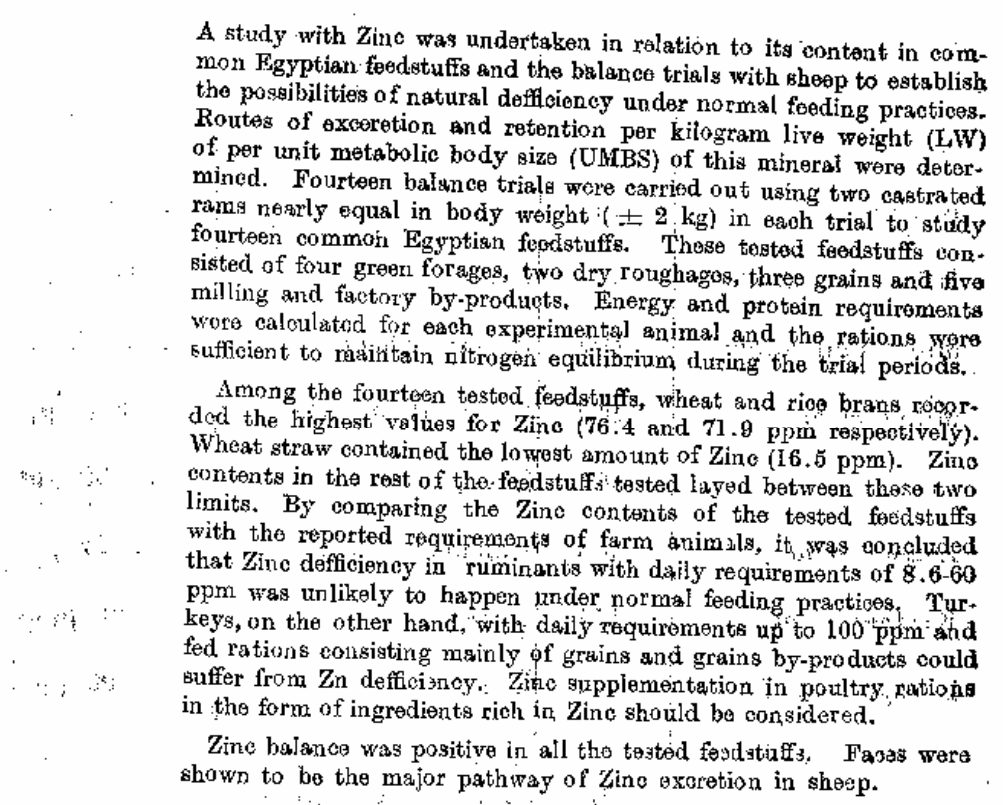

Modern work shows that Zine is a dietary essential. The functions of Zinc in the body are poorly und rrstood. It occurs in at least three enzymes: carbonic anhyrase, uricease, and kidney phosphatase; and is a part of erystalline insulin. It is wid ly distributed in the body and appears to be associated with proteins. Slight or moderate defficiencies of Zinc ( $\mathrm{Zn}$ ) in the ration would retard growth (Prasad et al., 1963), lowered feed efficiency (Newland et al., 1958, and Bieson et al., 1962), caused abnormal bone formation (Supplee et al., 1958, and Sullivan, 1931), and lowered fertility-(Haaranen and Hyppols. 1931). Phytic acid in soybean meal apparently inactivated some of the $\mathrm{Zn}$ in the ration and made it unavailable (Smith et al., 1961, and O'D sulfate, Zine carbonate, Zinc oxide and Zino metal was relatively arailable to young chicks. 
The amount of $\mathrm{Zn}$ required in a ration varic $\mathrm{d}$ with the type and level of other minerals in the different constituents of the ration. O'Dell et al. 1958, and Roberson and Sohaible (1960) found that increased calcium content of the ration caused a mariked increase in the $\mathrm{Zn}$ requirement of poultry. Hoefer et al., (1960) claimed that para-keratosis in swine occured at all calcium. levels and it was completely by Zn addition. Supplee $(1961,1963)$ found that high levels of cadmium raised the $\mathrm{Zn}$ requirements of turkeys and chicks. Kinnamon and Bunce (1965) found that growth was retaxted when molybidinum and $\mathrm{Zn}$ defficiencies were combined. The range of $\mathrm{Zn}$ requirements recorded by serveral workers for different animals could be summarized as follows :

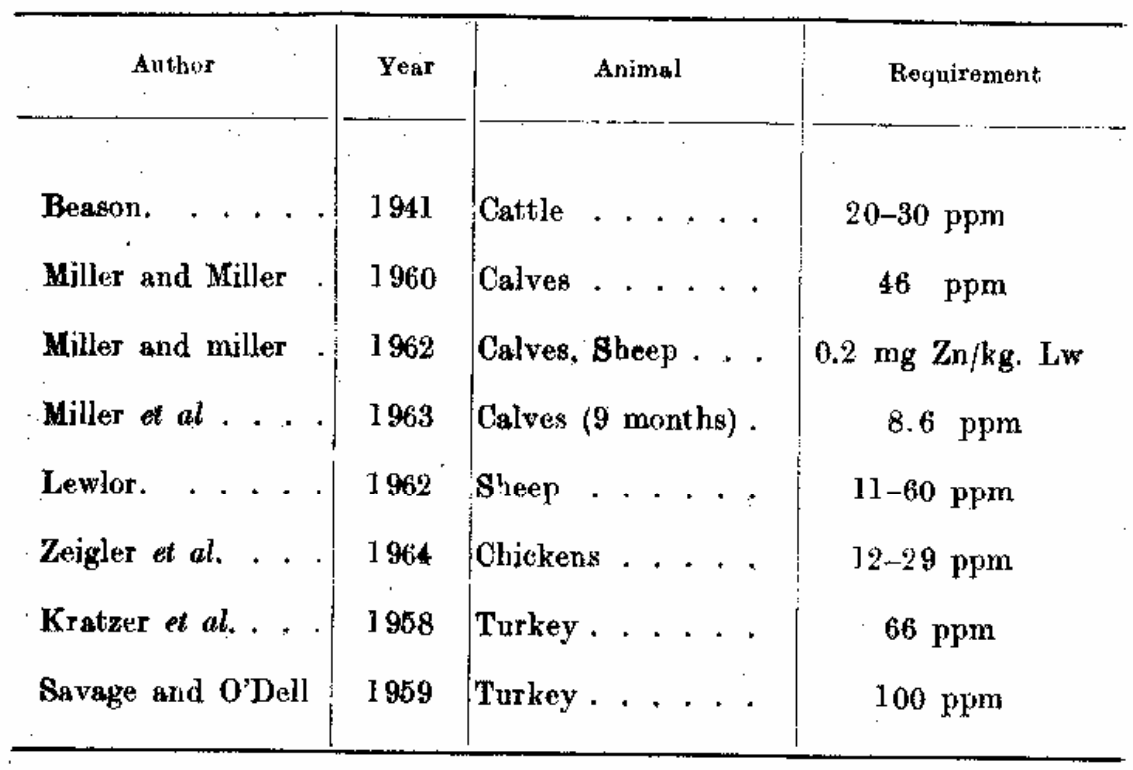

Materials and Methods

Fourteen balance trials were carried out to determine linc content and. retention from common Egyptian fédstufs using two castrated rams nearly equal in body weight $( \pm 2 \mathrm{~kg}$ ) in each trial. The inside surface of the: metabolic cages was covered with polyethylene sheets to prevent contamination of urine with Zine. Urine was collected in suitable polyethylene bottles anid faeces were collected in polyethylene bags. Water. was offered ad-libitum and daily water consumption was recorded. Both rations and water were offered in suitable polyethylene containers.

Energy reguirements as :tarch value was oaleulated for each experimental animal according to kiaiber (1961) using the following equetion :

Maintenance requirements in S.V. $=70 \mathrm{wkg} \cdot \frac{0.75}{100} \cdot \frac{1}{37 \mathrm{\epsilon}}$

where $\mathrm{W}=$ weight of the animal in kilograms. 
Proteins contents of the rations were enough to cover the maintenance requirement as $1.76 \mathrm{~g}$. digsstible protein/unit metabolic body size (UMBS) mented with 40 Kleiber (1961). When wheat straw was tested, it was suppleprotein for rams. casein per day to cover the maintenance requirements of when concentrates and hreen maized as a basal constituent of the ration maintenance requirements of starch were tested to supply half of the daily

The chemical analyses of teedstuffs and facal materials for moisture and nitrog 3 followed the ordinary conventional methods of A. O. A.C. $\mathrm{Zn}$ determinationples of feed stuffs, faeces, urine, and water, the modified spectrophotometer at a Harold et al., (1936) was applied. Unicum (

\section{Results and Discussion}

\section{Zine content in feedstuffs}

In roughagas, hay contained the highest amount of $\mathrm{Zn}$ and the lowest value was of the first eut clover when calculated on as fed basis. On dry matter basis, Zin content was the highest in hay and the lowest in wheat agreement with that found Zino content of hay obtained here was in. bat higher than that round by Ghoneim (1964) and Junganmann (1961), and wheat bran gave the hid by CNRC(1964). In oncentrates, rice bran. grains contained the lowe hest velues of Zinc while bavley and nuaize pointed out that $Z$. grains, corn grains, rice bran and $17.0,20.0,30.0$, and $80.0 \mathrm{ppm}$ in barley are in ag eement with those foud wheat bran respectively. These Figures bran which contained those fourd in this study except with the tested riee

By compare

mon comparing the results obtained in this study on $\mathrm{Zn}$ contents in comup to 100 ppm for tor requirements for farm animals (20-30 ppm for cattle rations as they for turkeys), supplementing $Z$ an appearco necessary in turkey which contain fed on varicty relatively low anounts of $\mathrm{Zn}$. It is unlikely that ruminanits noed $\mathrm{Zn}$ supplementation.

\section{Zinc excretion}

With roughag the percent urinary Zinc excretion ranged between 12.95 and $20.04 \%$. The high urinary excretion percent in wheat straw may be due to the presence of casein in the ration. In this connection may and Zieglar (1963) found that casein improved $\mathrm{Zn}$. absorption. With conas shown in Table (1). The previne ranged between 12.54 and $17.1 \%$ of Mc Conce and widdowion previous results are in harmony with those (1943), and speneer et al., (1955) who reported Monthy et al., (1943), S'ieline was the major route of 


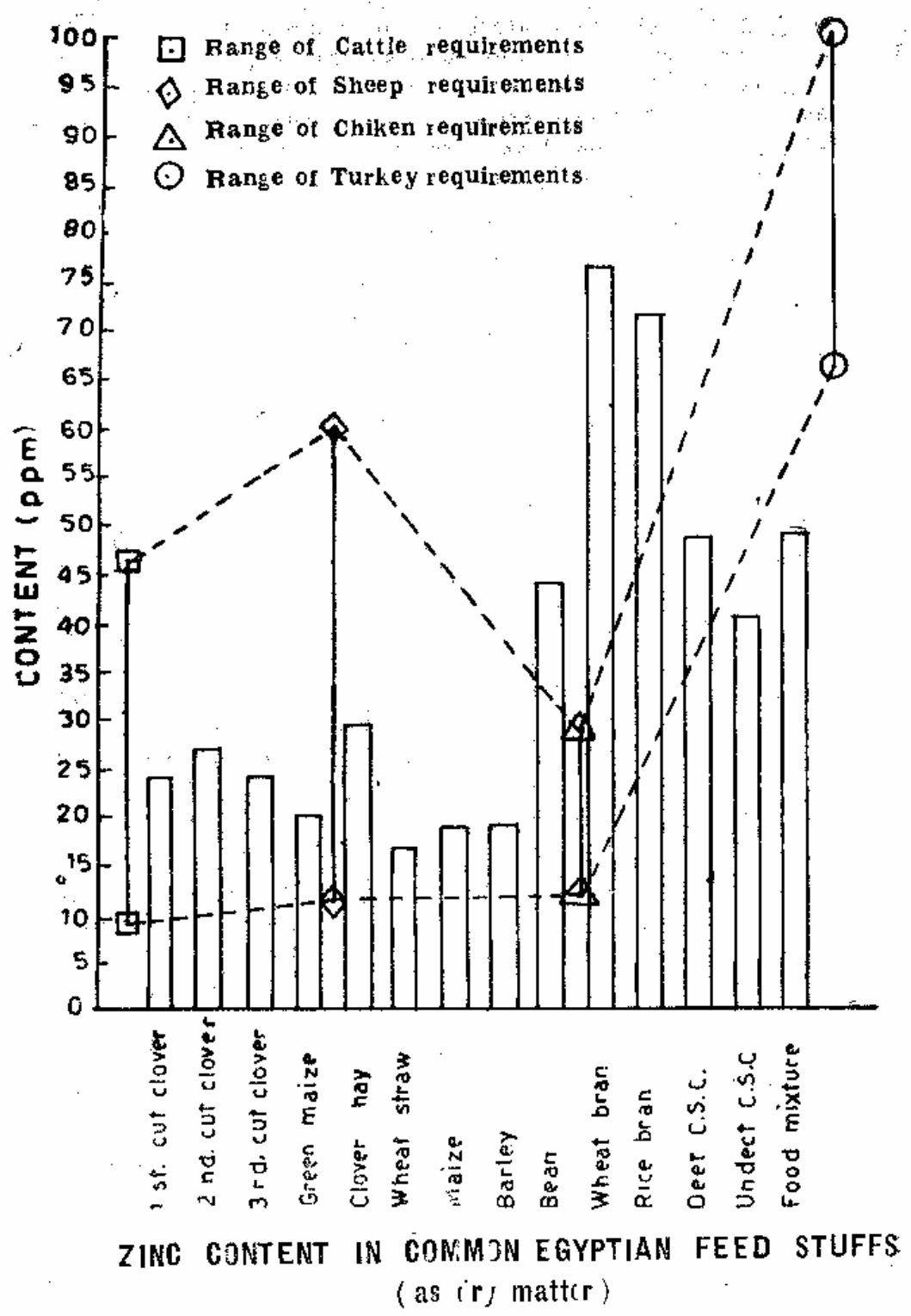

Bgypt. J. Anim. Prod., Vol. 12, No. 1 (1972). 
TABLE 1. - Averane Diny Zinc exoretron

\begin{tabular}{|c|c|c|c|c|c|}
\hline \multirow{2}{*}{ Feedstuffs } & \multirow{2}{*}{$\begin{array}{c}\text { Tutal } \\
\text { excroted }\end{array}$} & \multicolumn{2}{|c|}{ Zn excretiou } & \multicolumn{2}{|c|}{ Exoretion percont } \\
\hline & & in urine & in fạeces & in urine & in faeces \\
\hline Roughages & $\mathrm{Mg}$ & $\mathrm{Mg}$ & $\mathrm{Mg}$ & $\%$ & $\%$ \\
\hline I st cut clover ... & 8.(4) & 1.676 & 6.364 & 20.04 & 79.96 \\
\hline $2 n d$ cut clover & 13.220 & 1.940 & 11.280 & 14.68 & 85.32 \\
\hline $3 r d$ out Clover. . . & 16.4 .6 & 2.128 & 14.298 & 12.95 & 87.05 \\
\hline Green maize & 20.446 & 3.414 & 17.032 & 16.70 & 83.30 \\
\hline Clover hay $\cdot . \cdots$ & 17.882 & 2.680 & I5.202. & 15.06 & 84,94 \\
\hline Wheat straw . . . & 6.331 & 1,090 & 5.241 & 17.20 & 82.80 \\
\hline \multicolumn{6}{|l|}{ Concentrates } \\
\hline Maize grains $\ldots \ldots$ & 18.150 & 2.981 & 15.169 & 16.42 & 83.58 \\
\hline Barley grains . : . & 17.729 & 2.982 & 14.747 & 16.81 & 83.19 \\
\hline Bsan graina . . & 18.480 & 3.035 & 15.445 & 16.44 & 83.56 \\
\hline Wheat bran $\ldots \ldots$ & 33.774 & 4.255 & 29.519 & .12 .54 & 87.46 \\
\hline Rice bran $\cdots \cdots$ & $22: 475$ & 3.848 & 18.627 & 17.10 & 82.90 \\
\hline Dec. Cotton. S.C. . . & 24.898 & 4.208 & 20,690 & 16.90 & 83.10 \\
\hline Undect. Cotton. S.C. & 21.008 & 3.056 & 17.952 & 14.54 & 85.46 \\
\hline Feed mixture. $\ldots$ & 28.126 & $3: 892$ & 24.234 & 13.84 & 86.16 \\
\hline
\end{tabular}

Egypt. J. Anin. Prod., Vol. 12, No. 1 (1972): 


\section{Zinc retention}

\subsection{Roughages}

Zinc balance was positive in the three cuts of clover as shown in Table: (2). Concernir g Zn retention per kilogram liveweight (IW) or per unit: metabolic bc dy size (UMBS) the results is dicated that the bighest retention value was in the 2nd eut clover. Abd-Elmotagalli (1966) fou d that the $2 n d$ cut clover was the lowest in calcium compared with that of the 1 st and. $3 r d$ cuts. In this connection. Lewis et al. (1956) found that inereased. dietary calcium decreased $\mathrm{Zn}$ absorption. The results obtained here in agreement with their firdirgs. With gceen maize, $\mathrm{Zn}$ balance was positive. 'The retention percent was lower than that of the l st ar d and cut clover, but: higher than that of the 3 rd cut. The results indicated that the amoint, retained per $\mathrm{kg}$ LW or per UMES was higher than that of the different cuts. of clover.

Zinc balance was positive in both clover hay and wheat straw. $\mathrm{Z}_{12}$ retention percent in hay was lower than that in wheat straw. The results. indicated that both $\mathrm{Zn}$ retained per $\mathrm{kg} \mathrm{LW}$ and per UMBS were higher in hay than that in wheat straw plus casein. These results are in agreement: with the results of Moeller (1958), Morrison and Sarett (1958), and Pensack: et al., (1958).

\subsection{Concentrates}

Positive $\mathrm{Zn}$ balance was obtained with all grains and by-Products.. Zinc retention values were the same when the animals fod grains (Table 3 ). The retention per $\mathrm{kg} \mathrm{LW}$ and per UMBS was the highest in broed beans. followed by barley ar d maize grains. Within the by-prcducts, wheat bran. gave the highest values of $\mathrm{Zn}$ retention per $\mathrm{kg} \mathrm{LW}$ or per UMBS while decorticated cottonsecd cake gave the lowest values.

From the previous data it can be concluded that the level of $Z$ ine in the tested common Egyptian feed stuffs could provide sufficient amounts of: Zinc for ruminats. When zinc contents of normal constituents of poultry ration, especailly turkey's' ration, was compared with their requirements, the possibility of Zine deficiency could be a problem. Supplementation of turkeys "ration with Zine was suggested. The addition of casein to a ration of plant sources increased Zinc availability and absorption as clarified by the increased urinary excretion of Zine under such feeding practices.. The gastrc-intestinal tract was the major excretion pathway of Zine in sheep.

Egypt. J. Arim. Prod., Vol, 12, No. 1 (1972): 
TABLE 2. - DALLY RETENTION OF ZINC PER KG LM OR PER UMBS

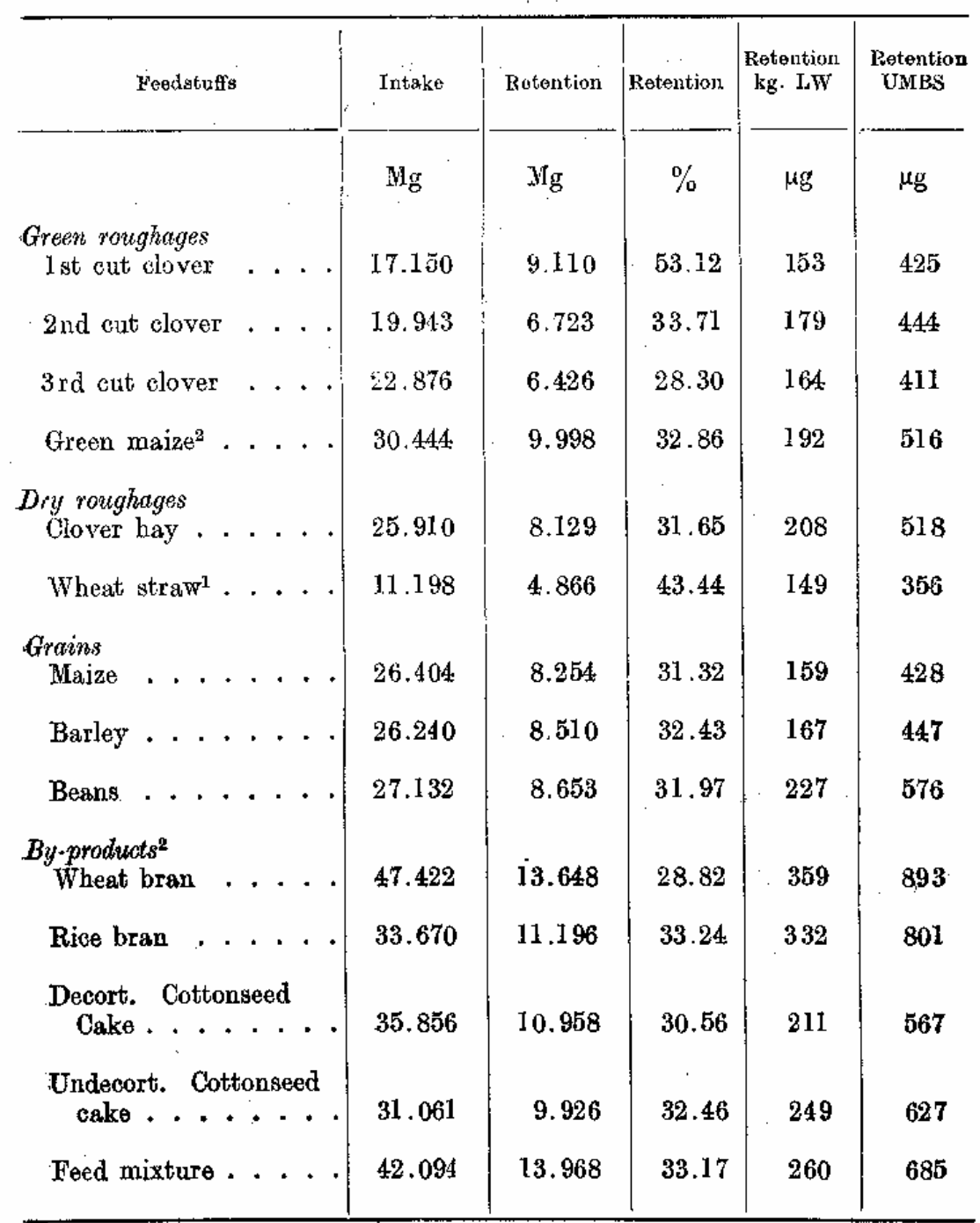

1. Supplemented with 40 grams orsein/auimal/day.

2. Half of the energy requiremunt was overed from elover hay. 


\section{References}

And-ELmotagald., M.Z. (1966). Chemical studies on the mineral constitutents of some Egyptianfoodstuffs. M.Se. Thesis, Faculty of Agric., Cairo Univ.

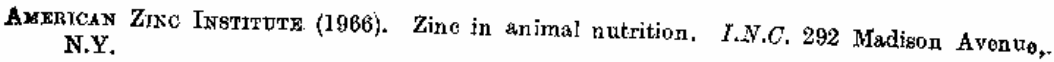

A.O.A.C. (1960). "Oficial method of analysis", oth Edit. Association Offcial Agricultural:
Chemists.

Beeson, K.C. (1941). U.S. Dept. Agric. Med. Pub. No. 369. (Underwood, E.J. 1962).

BeEson, K.C., SMixh. W.H., Perry. T W. and Mohter. M.T. (1982) Effect of Zinc supplo mentation on growing-fattening steors, F' Fedstuffs. 34, No. 18, 54. Canadian National Research Counch (CNRC), (1964). Canadian tables of feed composition.
Publ. No. 1832.

EDwards, H.H. Yoexc, R.T. and Grors, M.B. (1958). Studies on Zino in poultry nutrition. Ponttry Sci. 37, 1004 .

Gronmim, A. (1964). "Animal Nutrition" 2nd Edit. Anglo Egyptian Libr. Cairo (In Arabic). HAARANiN, S. and Hrrpola, K. (1961). Cure and prevention of dairy cattle itoh and hair
slicking with Zine. Feedstuffs. 33 ; No. 46,28 .

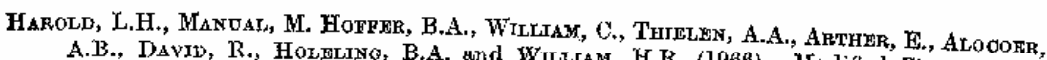
A.B., DAVID, R., HozgLINo, B.A. und WILICAM, H.R. (1966). Modified Zino analysis.
method and serum and urinary Zine leveIs in method and serum and urinary Zine leveis in control subjects. Amor. J. Chin. Path.
54, 160 .

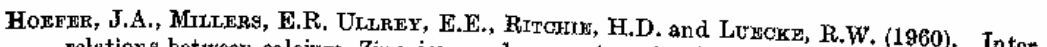
relatione between calciun, Zinc, iron and copper in swine feeding. J. Animal Nei., 19,: 249 ,

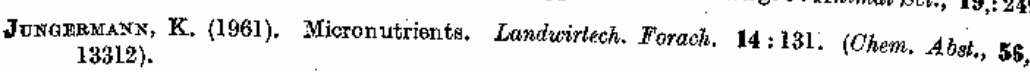

Kinnamon, K.E., and Bunce, G.E. (1965). Effect of oopper, molybdenum and Zine on $\mathrm{Zn}^{* 5}$,
tisauc distribution and excretion in the rat. J. Nutr., 86,225 . KLerber M. (1961). "The Fire of Life". An introducion to animal energetics, 30. H.N.
Willy \& Sons. Jnc. N.Y. London.

Kratzer, F.H., Vohra, P. Allked, J.B. and Davis, P.N. (1958). Effect of Zinc on gro w th and incidence of perosis in turkey pouletk. Proc. \$oc. Exptl. Biol. Med. 98, 205.

LAwross, M.J. (I962). A study of amipurified diets the iron requirements and the Zinc-B vitamin interrelationships for sheep. Disseriation Abstr., 23,377. (Amerion Zine In.
etitute 1966).

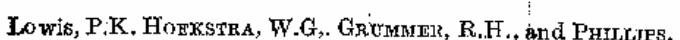
nutritional factore nutritional factors including calcium phosphorus and Zinc on para-keratosis in sivine.
J. Animal Sci., 15, 741.

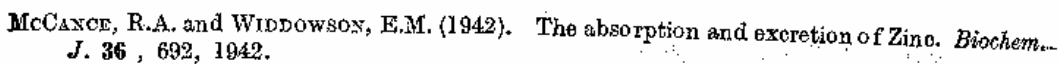

Equpt. J. Anim. Prod., Vol, 12, No. 1 (1972). 


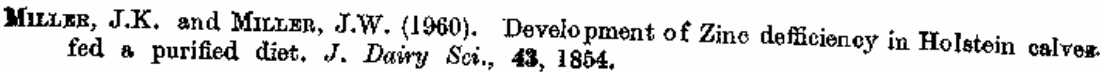
MhLer, J.K. and MrLise, J.W. (1962); Experimental Zine defficienoy and recovery of ealvem,
J. Nutr., 76, 467.

Mizter, W.J., Criston C.M., and CAMgron, N.W. (1963). Zine requirement of Holstein bull ealves to nine months of age. J. Dairy \$ci., $\mathbf{4 6}, 715$. Zinc requicement of Holstein bulk

MorrLzak, N.W. (1958). Studies with purified diots. 3. Zine requirement. Poultry Sci, 3\%,
1227.

Montogomery, M.L., Sheline, G.E. Ciratkort, L.L. (1943). J. Expt. Med., 78, I51. MORRISON, A.B. and SARRET, H.P. (1958). Studies on Zino defficiency in the chieks. J. Nutr.
65, 267.

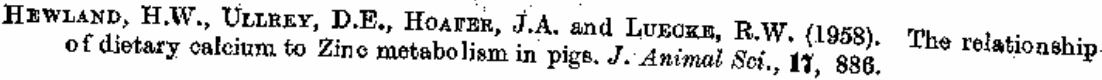

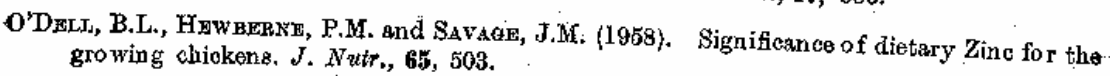
O'Dezi, B.L. and Savaan, J.E. (1906). Effect of phytic acid on Zinc availability. Proc. Soc.
Exp. Biol. Med., 103, 304.

Ponsack, J.M., Henson, J.N. and Bogdonoff, P.D. (1958). The effect of calcium and phon. phous on the Zinc requirementis of growing chickens; Poultry Sci., $\mathbf{3} \%, 1232$.

Prasad, A.S., Schulert, A.R., Mrade, A., Farid, Z. and Sendotead, H.H. (1963). Zine and
iron deffieiencies in male subjects with dwarfigm iron deffieiencies in male subjects with dwarfism anc hypogonadism but without ancy. lostomiatis, schistosomiasis or severe anemia. Am. J. Clin. Nutr., 12, 437. Roberson, R.H. and SCHaible, P.J. (1960). The availsbility to the chick of Zine ss the
sulfate oxide or carbonate. Poulley Sci, 39, 835.

SAVAGE, J.B. and O'DeLt, B.L. (1959). The requirenent of poultry for Zinc. Proc, Dietilers fed Conf,, 14th Conf., Cincinnati, 41, 51, (Chom, Abst, 53, 172581). Scott, M.L., and ZtEGLRR, T.R. (1963). evidence fornatural ohelates with acid in the util
zat. on of Zine by ehicks. J. Agr. Food-Chem, 11, 123.

Bhyune, G.E., Jones, H,B, and Hontogomery, M.L., (1043). Studies on the motebolis of Zine with the aid of its radioactive iso tope J. Biol. Chem., 147, 409 . motabolis $m$

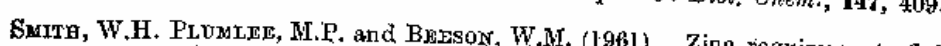
fed soybean protein emipurified ration. J. Anim. Sci., $\mathbf{2 0}, 128$,

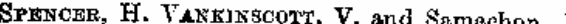
high eslcium intake in man. J. Nutr., 86, 169 . Zinest metabolism during low and

Suluvan, T.W. (I96l) 40, 334.

SUPPLEE, W.C. COMEO, G.F. and BLAMBeRg, D.L. (1958). Zino and potassium effects on bone formation feathering and growth of poults. Pouttry $S_{c i}, 3 \%, 83$.

SurPJ,I7n, W.C. (1961). Production of Zine defficioncy in turkey poults by diotary cadmium Poullry Sci, 40, 827. SuPpLE:, W.C. (1983). Antogonjstic relationship between dietary cadmium and Zine. Science,
139, 119.

UNDERwoon, E.J. (1962). "Trace element in human and animal nutrition". Ind Edit: Acade-
mic press. N.Y. \& London.

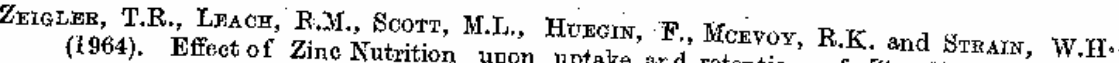
J. Nutr., 82,489 .

Elgipt. J. Anim. Prod., Vol. 12, No. 1 (1972). 


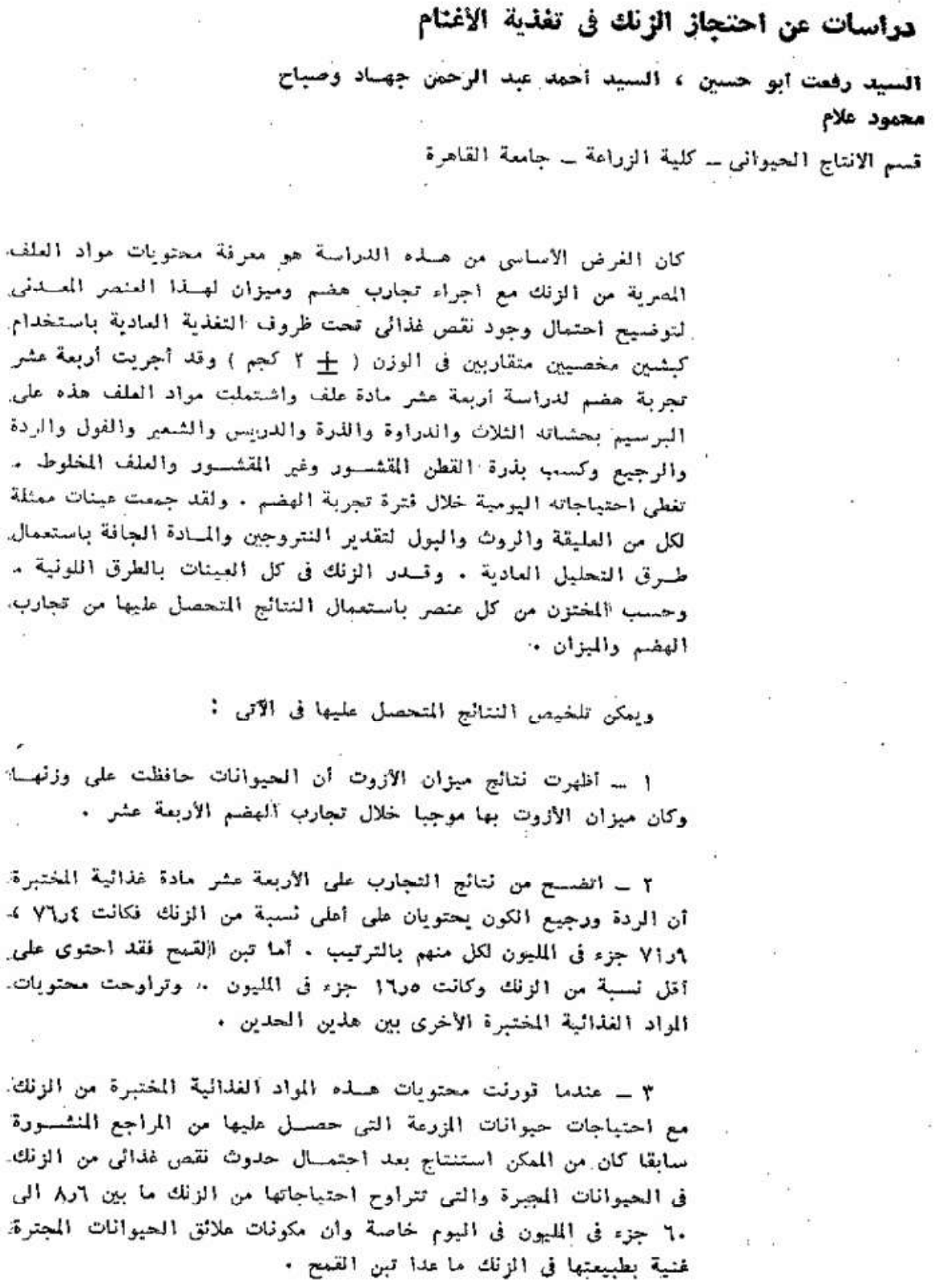

Egypt, J. Anim. Prod., Vol. 12, No. 1 (1972). 


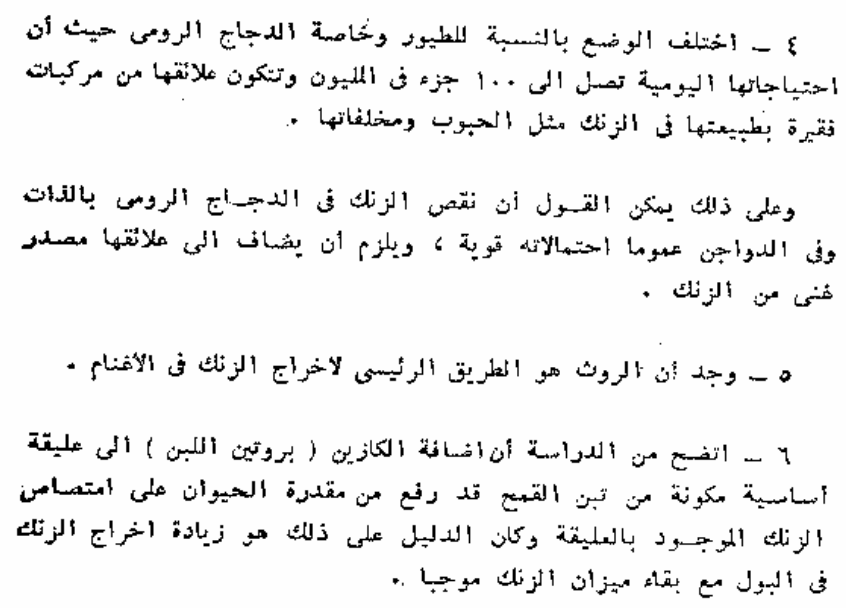

Igypt. J. Anim. Prod., Vol. 12, No. 1 (1972). 